\title{
Release of dipicolinic acid from spores of Geobacillus stearothermophilus
}

\author{
Reyes Alvin T1,2* Ambita Dave'1, Batalon Jamie Louise ${ }^{1}$, Aba Berna Lou ${ }^{1}$, Cortes Angelbert ${ }^{1}$, \\ Macabecha Cherray Gabrielle ${ }^{1}$ and Montecillo Andrew ${ }^{1}$ \\ ${ }^{1}$ University of the Philippines Los Baños, College Laguna Philippines; \\ ${ }^{2}$ College of Fisheries-Freshwater Aquaculture Center, Central Luzon State University, Science City of Muñoz, Nueva Ecija, Philippines
}

\section{ABSTRACT}

The effect of eight pH suspensions $(2,4,6,7,8,10,12$ and 14) and four heating times (5, 15, 30 and 60 minutes) on the release of dipicolinic acid (DPA) from spores of Geobacillus stearothermophilus was evaluated. The pattern of DPA release from spores of the bacterium exhibited two peaks, one at pH $4(41.75 \mathrm{ug} / \mathrm{mL})$ and the second at $\mathrm{pH} 7(43.25 \mathrm{ug} / \mathrm{mL})$. One-way ANOVA showed that the DPA released at pH 4 and $\mathrm{pH} 7 \mathrm{was}$ significantly higher as compared to other $\mathrm{pH}$ DPA values $(\mathrm{p}<0.05)$. Maximum release of the acid from the spores of G. stearothermophilus was achieved after 30 minutes of autoclaving at $121^{\circ} \mathrm{C}$. The maximum level of DPA obtained was $177 \mathrm{ug} / \mathrm{mL}$ which was four times higher as compared to the maximum DPA released in the $\mathrm{pH}$ experiment. One-way ANOVA showed that the DPA released after 30 minutes autoclaving was significantly higher as compared to DPA released in other heating times $(\mathrm{p}<0.05)$. Basing from the result obtained in the study of Rotman and Fields (1969), the variant that was used in this exercise was the smooth type because of the comparable peak of DPA at pH 7 and lower heat resistant with maximum release of DPA after 30 minutes of autoclaving at $121^{\circ} \mathrm{C}$.
\end{abstract}

Keywords: Dipicolinic acid, Geobacillus stearothermophilus, spores, temperature, pH

Article Info: Received 12 July 2019; $\quad$ Review Completed 19 August 2019; $\quad$ Accepted 26 August 2019; Available online 15 Sep 2019

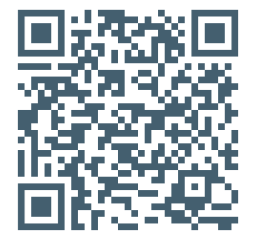

\section{Cite this article as:}

Reyes AT, Ambita D, Batalon JL, Aba BL, Cortes A, Macabecha CG, Montecillo A, Release of dipicolinic acid from spores of Geobacillus stearothermophilus, Journal of Drug Delivery and Therapeutics. 2019; 9(5):22-25

http://dx.doi.org/10.22270/jddt.v9i5.3562

Reyes Alvin, College of Fisheries-Freshwater Aquaculture Center, Central Luzon State University, Science City of Muñoz, Nueva Ecija, Philippines

\section{INTRODUCTION}

The vegetative cells of Bacillus species undergo sporulation under nutrient-limited conditions ${ }^{1,2}$. The resulting spores are characterized as metabolically dormant, resistance to heat and other potentially lethal treatments which include radiation, high pressure, chemicals and desiccation. Spores' resistance is considered an important obstacle to food preservation. However, the properties mentioned above are lost during the process of germination, being triggered by the availability of nutrients ${ }^{3}$.

According to Setlow and Johnson ${ }^{4}$, the heat resistance of spores is modulated by a number of factors which include: (i) small-acid soluble proteins that protect the DNA, (ii) accumulation of divalent cations, (iii) dehydration of spore core and (iv) dipicolinic acid.

Dipicolinic acid (DPA, pyridine-2,6-dicarboxylic acid) was discovered by Powell 5 in bacterial spores. DPA is involved in spores' dormancy, wet-heat resistance and germination. According to Church and Halvorson', DPA is $5-15 \%$ of spores' dry weight. The high core Ca-DPA level helps to reduce core water content, an important element in spore resistance to wet heat, and Ca-DPA also plays a more direct role in protecting spore DNA against several types of damage $e^{7,8,9,10}$. Its synthesis happens in a sporulating cell in one step from dihydroxydipicolinic acid, an intermediate in lysine biosynthesis. DPA is transported from the mother cell compartment over the outer and inner membranes of the forespore. The proteins involved in DPA transport are encoded by the spoVA operon ${ }^{11}$; the DPA synthase is encoded by the two genes of the spoVF operon ${ }^{12}$. Therefore, mutations in spoVF locus will result to significant increase of spore core water content that will eventually lead to decrease in heat resistance 8 .

Release of DPA from bacterial spores occurs in three conditions: (i) DPA is freed from spores in the first minute of germination, when nutrients bind to the germinant receptors. The process of release occurs simultaneously with the release of cations, the uptake of water and the loss of the phase-bright appearance of the spore13,14,15; (ii) DPA is released when an endospore's structural integrity is compromised by chemicals, heat, high pressure, so by hydrolysis of the large peptidoglycan cortex of the spore and; (iii) DPA is released during wet-heat-induced spore 
inactivation. The release of DPA is connected with the activation of the spore cortex by lytic enzymes (CLE), which are responsible for degradation of the cortex ${ }^{16,17,18,19}$.

Release of DPA from spores' proceeds at a slower rate than loss of viability of spores during heating ${ }^{20}$, or loss of heat resistance during spore germination ${ }^{21}$. Many studies have shown that differences in the amount and type of cation strongly affect spore heat resistance $22,23,4,24$.

The effect of eight pH suspensions $(2,4,6,7,8,10,12$ and $14)$ and four heating times $(5,15,30$ and 60 minutes) on the release of DPA from spores of Geobacillus stearothermophilus was evaluated in this experiment.

\section{MATERIALS AND METHODS}

\section{Preparation of Spore Suspension}

A 24-hour broth culture of G. stearothermophilus was streaked onto nine pieces of $100 \mathrm{~mL}$ modified nutrient agar in flat bottles. The bottles were incubated for 11 days at 45 $50{ }^{\circ} \mathrm{C}$. The bottles were individually flooded with $10 \mathrm{~mL}$ distilled water to scrape the surface growth using wire loop. The bacterial suspensions were transferred in falcon tubes and were centrifuged for 5 minutes at $10,000 \mathrm{rpm}$. The supernatant from each falcon tube was discarded. The suspensions of compacted spores and vegetative cells were combined and recentrifuged, decanted and volumed to 50 $\mathrm{mL}$. Lysozyme $(0.5 \mathrm{mg} / \mathrm{mL})$ was added and then incubated for 3 hours in room temperature with vigorous shaking. The endospores were stained following the Schaeffer-Fulton method and viewed under the microscope.

\section{Cleaning of Spores}

The spore suspension was transferred in falcon tubes and was centrifuged for 5 minutes at $10,000 \mathrm{rpm}$; the supernatant was discarded. The spores were resuspended in $50 \mathrm{~mL}$ distilled water. Washing and centrifugation were repeated 10 times.

\section{Effect of pH on Release of DPA}

Four millilitres of spore suspension was transferred into each of 16 dram vials (two replicates per $\mathrm{pH}$ suspension). The $\mathrm{pH}$ of the suspension was adjusted to $2,4,6,7,8,10,12$ and 14 , respectively using $1.0 \mathrm{~N} \mathrm{HCl}$ or $1.0 \mathrm{~N} \mathrm{NaOH}$. The dram vials were autoclaved for 15 minutes at $121^{\circ} \mathrm{C}$. The $\mathrm{pH}$ of the suspension was adjusted to 6.5 after cooling. The final volume of the suspension was adjusted to $5 \mathrm{~mL}$. Afterwards, the concentration of DPA was determined.

\section{Effect of Heating Time on Release of DPA}

Five millilitres of spore suspension was transferred into each of 8 dram vials (two replicates per heating time). The dram vials were autoclaved at $121^{\circ} \mathrm{C}$ for $5,15,30$ and 60 minutes. Afterwards, the concentration of DPA was determined after cooling the suspensions.

\section{Calorimetric Assay of DPA in Bacterial Spores}

The $5 \mathrm{~mL}$ spore suspension was acidified with $0.1 \mathrm{~mL}$ of 1.0 $\mathrm{N}$ acetic acid. After 1 hour, the suspension was centrifuged at $10,000 \mathrm{rpm}$ for 5 minutes. One millilitre of freshly prepared reagent $\left(1 \% \mathrm{Fe}\left(\mathrm{NH}_{4}\right)_{2}\left(\mathrm{SO}_{4}\right)_{2} .6 \mathrm{H}_{2} \mathrm{O}\right.$ and $1 \%$ ascorbic acid in $0.5 \mathrm{M}$ acetate buffer at $\mathrm{pH}$ 5.5) was added in the supernatant. The absorbance $(440 \mathrm{~nm})$ was read using spectrophotometer.

\section{Preparation of Standard Curve}

DPA concentrations of 30,60, 90, 120 and $150 \mathrm{ug} / \mathrm{mL}$ was prepared. Four millilitre of each concentration was transferred into separate tubes and treated with $1 \mathrm{~mL}$ freshly prepared reagent. The absorbance $(440 \mathrm{~nm})$ was read using spectrophotometer

\section{RESULTS AND DISCUSSION}

Presented in Figure 1 was the stained endospore after the bacterial suspension was treated with lysozyme.

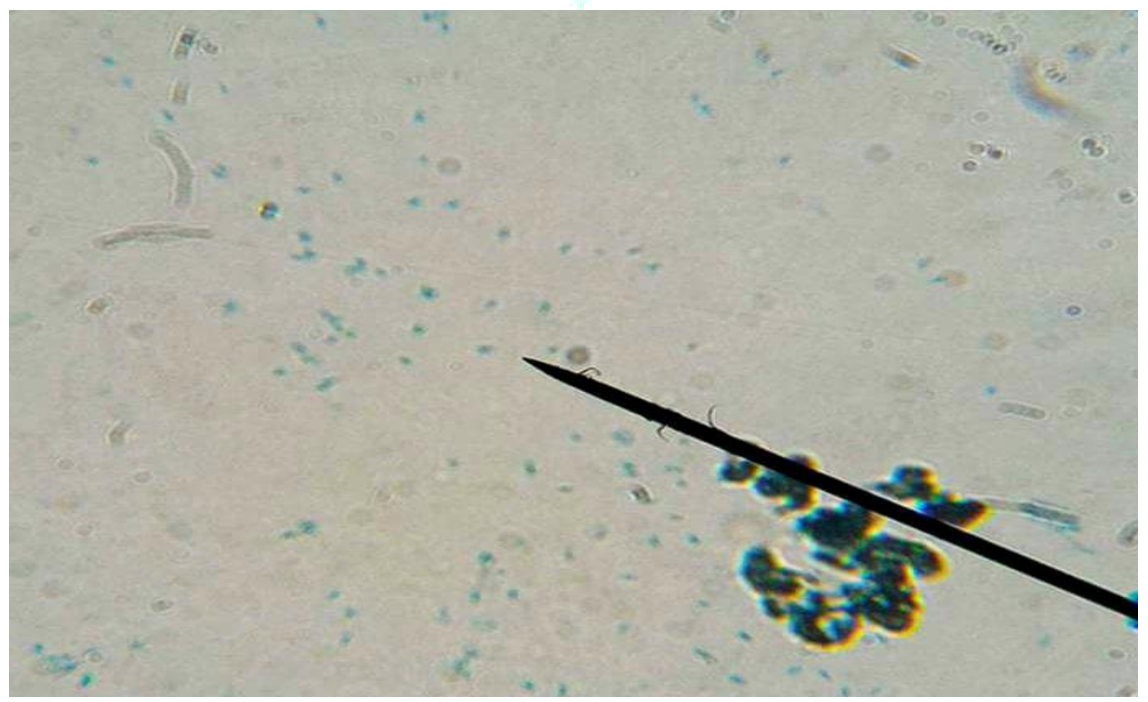

Figure 1.Stained spores of $G$. stearothermophilus (green) using Schaeffer-Fulton method, at 1000x magnification.

\section{Effect of pH}

The release of DPA from spores of G. stearothermophilus was being influenced by the $\mathrm{pH}$ of the suspension. The pattern of DPA release from spores of the bacterium exhibited two peaks, one at $\mathrm{pH} 4(41.75 \mathrm{ug} / \mathrm{mL})$ and the second at $\mathrm{pH} 7$ (43.25 ug/mL). One-way ANOVA showed that the DPA released at $\mathrm{pH} 4$ and $\mathrm{pH} 7$ was significantly higher as compared to other $\mathrm{pH}$ DPA values $(\mathrm{p}<0.05)$. At $\mathrm{pH} 10$, the least amount of DPA was released $(23.25 \mathrm{ug} / \mathrm{mL})$ and this might be connected to higher survival of the spores (Figure 2). However, Walker and Matches ${ }^{25}$ observed that the release of DPA was least at $\mathrm{pH} 7$ and this was also correlated to the high survival of spores at that particular $\mathrm{pH}$. Although the correlation between DPA release and the spore death 
rate was complex, in the study of Kort et al26, they found out that higher rates of death were associated with higher rates of DPA release.

In the study conducted by Rotman and Fields ${ }^{27}$, the smooth variant of $B$. stearothermophilus showed two peaks, at $\mathrm{pH} 7$ (41.4 ug DPA $/ 10^{8}$ spores) and $\mathrm{pH} 14$ (41.1 ug DPA/108 spores) while the rough variant maximum release of DPA happened at $\mathrm{pH} 14$ (39.5 ug DPA $/ 10^{8}$ spores). Also, they found out that the least amount of DPA was released at $\mathrm{pH} 8$ in both variants. Basing from the result obtained in the study of Rotman and Fields, the variant that was used in this study was the smooth type because of the comparable peak of DPA at $\mathrm{pH} 7$.

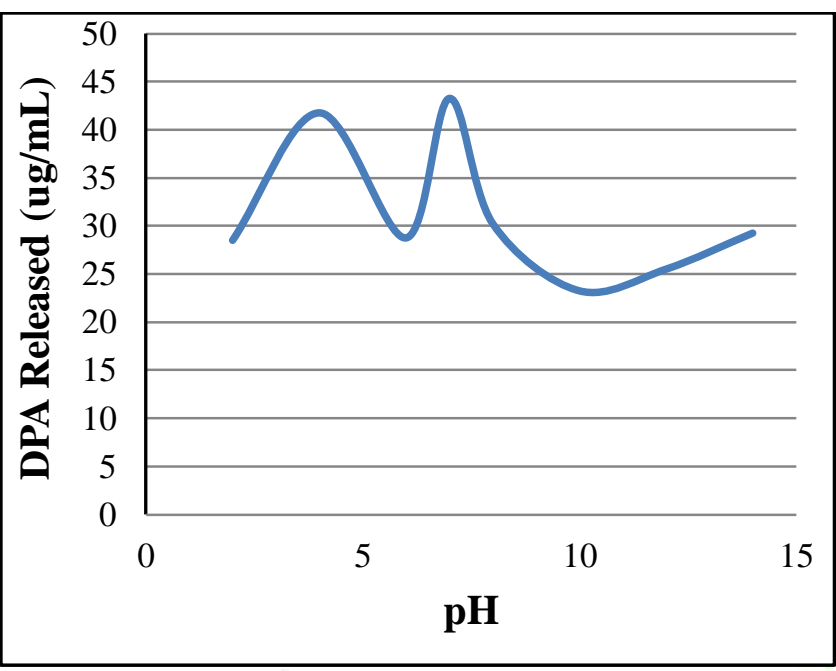

Figure 2. Effect of $\mathrm{pH}$ combined with heat (at $121^{\circ} \mathrm{C}$ for 15 min.) on the release of DPA from spores of $G$. stearothermophilus.

\section{Effect of Temperature}

Levinson and Hyatt 28 stated that when a bacterial spore suspension is subjected to thermal inactivation, it will result to progressive loss of DPA, proteins and other cell constituents. Rode and Foster 29 reported that a minimal temperature of $70^{\circ} \mathrm{C}$ was necessary for release of DPA.

Maximum release of the acid from the spores of $G$. stearothermophilus was achieved after 30 minutes of autoclaving at $121{ }^{\circ} \mathrm{C}$ (Figure 3). The maximum level of DPA obtained was $177 \mathrm{ug} / \mathrm{mL}$ which was four times higher as compared to the maximum DPA released in the $\mathrm{pH}$ experiment. One-way ANOVA showed that the DPA released after 30 minutes autoclaving was significantly higher as compared to DPA released in other heating times $(\mathrm{p}<0.05)$. In the study of Rotman and Fields 27 , maximum release of DPA from the spores of smooth and rough variants was achieved after 15 minutes (41.1 5 ug DPA $/ 10^{8}$ spores) and 70 minutes (39.5 5 ug DPA/108 spores) of autoclaving, respectively. It appeared that the variant we used in this exercise was more comparable to the smooth variant used by Rotman and Fields 27 because of lower heat resistant as compared to the rough variant. Spores with higher heat resistance will be requiring more adverse conditions such as longer autoclaving time to cause complete release of DPA. Rotman and Fields ${ }^{27}$ also found out that there was loss of spores' viability in the two variants after the complete release of DPA. Spores of smooth variant autoclaved for 30 minutes did not grow on dextrose tryptone agar at $55^{\circ} \mathrm{C}^{27}$.

In the study conducted by Walker and Matches ${ }^{25}$, they found out that spores with calcium-DPA ratio of one or more seem to release DPA more slowly than cells with calcium-DPA ratio of less than one. This only proves that certain levels of calcium and DPA are necessary to give heat stability to the spore.

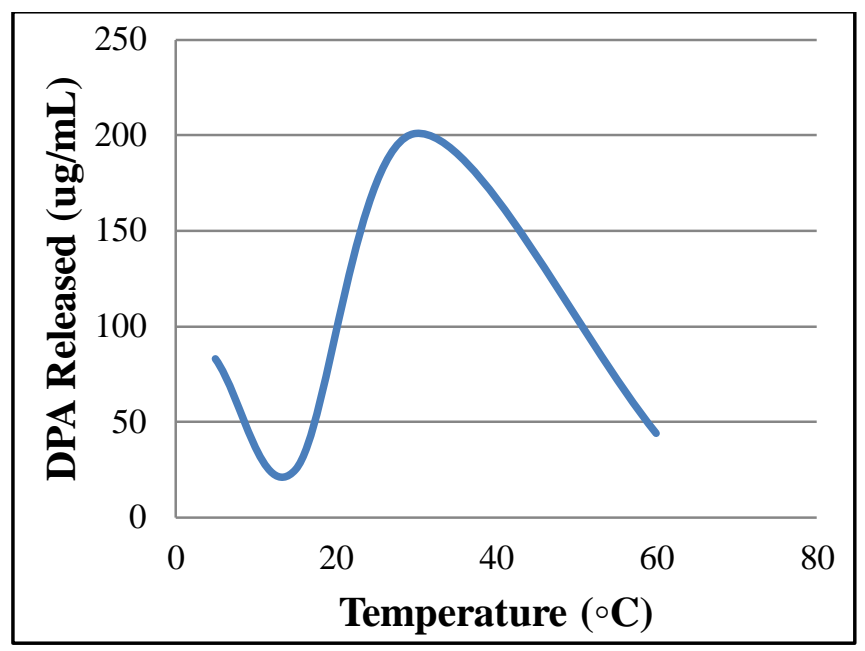

Figure 3. Effect of autoclaving time at $121^{\circ} \mathrm{C}$ on the release of DPA from spores of $G$. stearothermophilus.

\section{CONCLUSION}

The vegetative cells of Bacillus species undergo sporulation under nutrient-limited conditions. The resulting spores are characterized as metabolically dormant and resistant to heat and a number of lethal treatments. Heat resistance of spores is modulated by a number of factors that includes the dipicolinic acid (DPA). DPA is released when an endospore's structural integrity is compromised by chemicals, heat, high pressure, so by hydrolysis of the large peptidoglycan cortex of the spore.

The pattern of DPA release from spores of the bacterium exhibited two peaks, one at $\mathrm{pH} 4(41.75 \mathrm{ug} / \mathrm{mL})$ and the second at $\mathrm{pH} 7(43.25 \mathrm{ug} / \mathrm{mL})$. The DPA released at $\mathrm{pH} 4$ and pH 7 was significantly higher as compared to other pH DPA values $(p<0.05)$. Maximum release of the acid from the spores of $G$. stearothermophilus was achieved after 30 minutes of autoclaving at $121^{\circ} \mathrm{C}$. The maximum level of DPA obtained was $177 \mathrm{ug} / \mathrm{mL}$ which was four times higher as compared to the maximum DPA released in the $\mathrm{pH}$ experiment. One-way ANOVA showed that the DPA released after 30 minutes autoclaving was significantly higher as compared to DPA released in other heating times $(\mathrm{p}<0.05)$.

\section{REFERENCES}

1. Hilbert DW, Piggot, Compartmentalization of gene expression during Bacillus subtilis spore formation, Microbiology and Molecular Biology Reviews, 2004; 68:234-262.

2. Stragier P, Losick, Molecular genetics of sporulation in Bacillus subtilis. Annual Review of Genetics, 1996; 30:297-341.

3. Paidhungat $M$, Setlow $P$, Spore germination and outgrowth, $p$. 537-548. In A. L. Sonenshein, J. Hoch, and R. Losick (ed.), Bacillus subtilis and its closest relatives, ASM Press, Washington, D.C., 2002.

4. Setlow P, Johnson EA, Spores and their significance, p. 33-70. In M. P. Doyle, L. R. Beuchat, and T. J. Montville (ed.), Food microbiology: Fundamentals and frontiers, ASM Press, Washington, D.C., 2001.

5. Powell JF, Isolation of dipicolinic acid (pyridine-2,6dicarboxylic acid) from spores of Bacillus megatherium, Biochemical Journal, 1953; 54:210-211.

6. Church BD, Halvorson, Dependence of the heat resistance of bacterial endospores on their dipicolinic acid content, Nature, London, 1959; 183:124-125.

7. Gerhardt $P$, Marquis, RE, Spore thermoresistance mechanisms, p. 43-63. In I. Smith, R. A. Slepecky, and P. Setlow 
(ed.), Regulation of prokaryotic development. American Society for Microbiology, Washington, DC., 1989.

8. Paidhungat M, Setlow B, Driks, A, Setlow P, Characterization of spores of Bacillus subtilis which lack dipicolinic acid, Journal of Bacteriology, 2000; 182: 5505-5512.

9. Setlow B, Atluri S, Kitchel R, Koziol-Dube K, Setlow P, Role of dipicolinic acid in the resistance and stability of spores of Bacillus subtilis, Journal of Bacteriology, 2006;. 188:37403747.

10. Setlow P, Spores of Bacillus subtilis: Their resistance to radiation, heat and chemicals, Journal of Applied Microbiology, 2006; 101:514-525.

11. Tovar-Rojo F, Chander M, Setlow B, Setlow P, The products of the spoVA operon are involved in dipicolinic acid uptake into developing spores of Bacillus subtilis, Journal of Bacteriology, 2002; 184:584-587.

12. Daniel RA, Errington J, Cloning, DNA sequence, functional analysis and transcriptional regulation of the genes encoding dipicolinic acid synthetase required for sporulation in Bacillus subtilis, Journal of Molecular Biology, 1993; 232:468-483.

13. Woese C, Morowitz HJ, Kinetics of the release of dipicolinic acid from spores of Bacillus subtilis, Journal of Bacteriology, 1958; 76:81-83.

14. Dring GJ, Gould GW, Sequence of events during rapid germination of spores of Bacillus cereus, Journal of General Microbiology, 1971; 65:101-104.

15. Gould GW, Dring GJ, Biochemical mechanisms of spore germination, p. 401-408. In H. O. Halvorson, R. Hanson, and L. L. Campbell (ed.), Spores V. American Society for Microbiology, Washington, D.C., 1972.

16. Bevilacqua A, Ciuffreda E, Sinigaglia M, Corb MR, Spore inactivation and DPA release in Alicyclobacillus acidoterrestris under different stress conditions, Food Microbiology, 2015; 46: 299-306.

17. Magge A, Granger AC, Wahome PG, Setlow B, Vepachedu VR, Role of dipicolinic acid in the germination, stability, and viability of spores of Bacillus subtilis, Journal of Bacteriology, 2008; 190: 4798-4807.

18. Luu S, Setlow $P$, Analysis of the loss in heat and acid resistance during germination of spores of Bacillus species, Journal of Bacteriology, 2014; 196: 1733-1740.
19. Wang S, Setlow P, Li YQ, Slow leakage of Ca-dipicolinic acid from individual bacillus spores during initiation of spore germination, Journal of Bacteriology, 2015; 197:1095-1103.

20. Foster Jr. W, Dipicolinic acid and bacterial spores. Booklet containing text of lecture presented on 22 October 1959 at the University of Maryland, College Park, Maryland, 1959.

21. Wooley BC, Collierr E, Changes in thermoresistance of Clostridium roseurn as related to the intracellular content of calcium and dipicolinic acid, Canadian Journal of Microbiology, 1965; 11:279-285.

22. Brul S, Klis FM, Oomes SJCM, Montijn RC, Schuren FHJ, Coote $\mathrm{P}$, Hellingwerf KJ, Detailed process design based on genomics of survivors of food preservation processes, Trends in Food Science and Technology, 2002. 15:325-333.

23. Oomes SJCM, Brul S, The effect of metal ions commonly present in food on gene expression of sporulating Bacillus subtilis cells in relation to spore wet heat resistance, Innovative Food Science and Emerging Technologies, 2004; 5:307-316.

24. Murrel WG, Warth AD, Composition and heat resistance of bacterial spores, p. 1-24. In L.L. Campbell and H. O. Halvorson (ed.), Spores III. American Society for Microbiology, Washington, D.C., 1965.

25. Walker HW, Matches JR, Release of cellular constituents during heat inactivation of endospore of aerobic bacilli. Department of Dairy and Food Industry. Iowa State University of Science and Technology, Ames, Iowa 50010.

26. Kort R, Stokkum IHM, O'Brien AC, Oomes SJCM, Assessment of heat resistance of bacterial spores from food product isolates by fluorescence monitoring of dipicolinic acid release, Applied and Environmental Microbiology, 2005; 71(7):3556-3564.

27. Rotman Y, Fields $\mathrm{L}$, The release of dipicolinic acid from spores of Bacillus stearothermophilius NCA 1518, Journal of Food Science, 1979; Volume 34

28. Levinson HS, Hyatt MT, Some effects of heat and ionizing radiation on spores of Bacillus megaterium, Journal of Bacteriology, 1960; 80,441.

29. Rode LJ, Foster JW, Induced release of dipicolinic acid from spores of Bacillus megaterium, Journal of Bacteriology, 1960; 79,650 . 